\title{
The Historical Background to Japan's Peacekeeping Policy from the Early Postwar Era to the Establishment of the PKO Act 1945-1992
}

1 The Taboo Against the SDF's Deployment to the UNPKOs During the Postwar Era

\subsection{The Rise of Anti-militarism and the Controversial Birth of the SDF in 1954}

Since the Cold War era, the GoJ has attached much value to its relationship with the UN (Tanaka, 1997, pp. 207-201), but personnel contribution to the UNPKOs was not realized until the early 1990s. Behind this reluctance was a climate of deep-rooted anti-militarism in postwar Japan (Sado, 2015, 2017). Soon after the end of the war, Japan was demilitarized. In late 1945, the US-led Supreme Commander of Allied Forces, which occupied Japan after World War II, disbanded the Imperial Japanese Army and Navy almost completely (Yamagata, 2020). ${ }^{1}$

In 1947, the new constitution, or the Constitution of Japan (hereafter, "the Constitution"), which came into effect in 1947, institutionalized Japan's demilitarization. Notably, Article 9 laid the foundation for Japan's anti-militarism after World War II: ${ }^{2}$

Article 9 (1) Aspiring sincerely to an international peace based on justice and order, the Japanese people forever renounce war as a sovereign right of

H. N. Fujishige et al., Japan's Peacekeeping at a Crossroads, Sustainable Development Goals Series, https://doi.org/10.1007/978-3-030-88509-0_2 
the nation and the threat or use of force as means of settling international disputes.

(2) In order to accomplish the aim of the preceding paragraph, land, sea, and air forces, as well as other war potential, will never be maintained. The right of belligerency of the state will not be recognized.

Prime Minister of Japan and His Cabinet (1947)

First, Article 9 (1) declares that Japan will "renounce war as a sovereign right of the nation and the threat or use of force as means of settling international disputes." For this purpose, Article 9 (2) stipulates that "war potential will never be maintained." From these clauses, it was unclear whether Japan had relinquished even the right of national self-defense, although this was authorized by Article 51 of the UN Charter.

In the early postwar era, however, Article 9 was generally understood as the complete demilitarization of Japan, which meant that postwar Japan would not retain any armaments even for the purpose of national selfdefense. This view seemed credible, since Prime Minister Shigeru Yoshida (1946), a famous conservative politician, ${ }^{3}$ clearly denied Japan's right of national self-defense. Immediately after the promulgation of the Constitution, according to Japanese historian Takamine Kawashima (1997), a significant proportion of the Japanese population was initially perplexed or unsupportive of this extreme policy of Japan's demilitarization. By the 1950s, however, Article 9 gradually took deep root in Japan's political culture, nurturing the inclination toward anti-militarism-that is, a very strong aversion against the military as well as against war.

Behind the gradual rise of anti-militarism, a hidden rearmament was in progress. In 1950, the US government suddenly ordered the GoJ to rearm itself because most of the US occupation forces now had to be relocated to the Korean Peninsula to cope with the outbreak of the Korean War. This resulted in Japan's surreptitious rearmament under the guise of the "National Police Reserve (NPR)" (Kowalski, 2013; Kusunoki, 2017). From the perspective of its organizational structure, it appeared obvious that the NPR was an armed force, but Yoshida (1950) insisted that it was a police force. This made it unclear whether Japan was rearmed or not. To respond to continuing pressure from the US for a more substantial rearmament, the GoJ remodeled the NPR into the National Safety Forces in 1952 and then upgraded it to the SDF in 1954. Now it seemed certain that the SDF was indeed capable of national self-defense. If so, the Constitution must have entitled Japan to the right of national self-defense, 
but Yoshida kept this nebulous. Such an ambiguous situation necessarily raised doubt as to whether the creation of the SDF was compatible with the Constitution.

\subsection{Admitting the Constitutionality of the Right of National Self-Defense}

This problem was resolved in December 1954, five months after the establishment of the SDF, because the new government under Prime Minister Yukio Hatoyama, another influential conservative politician, changed the interpretation of the Constitution. The Hatoyama government admitted Japan's right of national self-defense and also declared the constructional legitimacy of the SDF (Omura, 1954). Even after this, however, the skepticism persisted as to the legitimacy of the SDF, combined with widespread hatred against the military and war. The left-wing parties, such as the Japan Socialist Party (JSP) and the Japan Communist Party (JCP), utilized the public aversion against the SDF to mobilize political support for themselves (Hara, 2000; Tachibana, 1983). ${ }^{4}$ As a result, these antimilitary parties considerably restricted the range of SDF roles in the postwar era.

The Hatoyama government's announcement in December 1954 also clarified the allowed range for the use of force by the SDF. SecretaryGeneral of Defense Sei'ichi Omura (1954) made the following statement at the House of Representatives (the Lower House):

[T] he Constitution does not deny [Japan's] right of national self-defense. $[\ldots][\mathrm{T}]$ he Constitution renounces war but does not renounce resistance through national self-defense. [...]. Upon facing an armed attack to our country, the use of force as a means to defend national territory does not violate the Constitution.

This new government's official standpoint rests on Article 51 of the UN Charter, which entitles each sovereign state to the right to national self-defense while strictly banning the "use of force" for any other purpose (UN Article 51). Based on this clause, the Hatoyama government now announced that the Constitution permits the minimal use of force only when Japan's territory is under armed attack (Mori, 2019, pp. 2-3). On the other hand, the use of force for any other purpose is strictly forbidden (Hayashi, 1961). The GoJ still maintains this official interpretation today. 
This rather simple official doctrine did not cause a particular problem during the postwar era, since no such case arose in which the SDF members actually faced the need to use arms for anything other than national self-defense. Once the GoJ began dispatching the SDF abroad from the 1990s onward, however, this simplistic stipulation encountered new questions, for example, as to whether the SDF's acts of protecting themselves would constitute the use of force, banned by the Constitution. This necessitated the GoJ to articulate more detailed legal logic about this issue (see Chaps. 3 and 4).

\subsection{The Taboo Against Overseas Military Dispatch}

In the meantime, distrust toward the SDF persisted, fueled by concern that it might be used for aggression against neighboring counties again. To prevent this, the House of Councilors (the Upper House of the Diet) adopted a resolution in June 1954, a month before the creation of the SDF, to ban its overseas dispatch (House of Councilors, The National Diet of Japan, 1954). Although this resolution had no formal legal force, the legislature's will was respected and it formed a de facto ban on the overseas dispatch of the SDF. From the time of its establishment, the geographical sphere of the SDF's activities was thus strictly limited within Japan's territory, even though the Constitution has no specific stipulation forbidding military deployment beyond national boundaries. The adoption of this resolution, as political scientist Akihiko Tanaka (1997) points out, reflected the political atmosphere, in which overseas military dispatch was regarded as "the root of all evils" in light of a bitter memory of prewar Japan (p. 180). As a result, the possibility of any military contribution to a UNPKO was completely excluded from its policy options (Kato, 2020). The taboo against military dispatch abroad was thus firmly embedded at the core of anti-militarism under the single-party dominance of the ruling Liberal Democratic Party (LDP), which was formed by the union of two conservative parties in 1955.

Despite the GoJ's professed UN-centrism, the troop contribution to UNPKOs was not an exception under the de facto ban on overseas military dispatch. When the UNSG Dag Hammarskjöld asked the GoJ to contribute SDF troops to UNPKOs in Lebanon (UN Observation Group in Lebanon: UNOGIL) in 1958, the GoJ immediately declined these requests, flatly justifying its response by stating that overseas military deployment would never be available as an option (Hatakeyama, 2018). 
In February 1961, when the UNPKO was being operated in the Republic of Congo (United Nations Operation in the Congo: ONUC), the Japanese Ambassador to the UN, Koto Matsudaira, asserted that the GoJ should dispatch the SDF to the ONUC ("Kongo he jiei-tai," 1961). This invited acute criticism from the anti-military camp. One of the JSP Diet members, for example, harshly condemned Matsudaira's assertion as follows: "I can never forgive it because it precisely embodies the change to the Constitution for the worse."

To be precise, as seen earlier, the Constitution does not have a specific stipulation to proscribe overseas military contribution. On the contrary, one could argue that the SDF's participation in a UNPKO could be compatible with the Constitution in light of its preamble: "We desire to occupy an honored place in an international society striving for the preservation of peace" (Prime Minister of Japan and His Cabinet, 1947). Whatever the truth was, Matsudaira's statement brought a fierce backlash. Prime Minister Hayato Ikeda (1961) accused Matsudaira's statement as a subtle attempt to give the impression that the overseas deployment of the SDF was becoming realized. The Matsudaira incident had an unintended impact by further fortifying the taboo against overseas military dispatch (Tanaka, 1997, p. 214).

Meanwhile, the Matsudaira statement also brought an unexpected byproduct by opening the possibility for the contribution of the SDF to a UNPKO in the future. Immediately after Matsudaira's statement, Director-General of Cabinet Legislation Bureau Shuzo Hayashi (1961) articulated that the GoJ could not deploy the SDF to a UNPKO because the SDF Act included no such provision, even though the Constitution did not outlaw overseas military dispatch. In other words, it could become possible if a new law were ever adopted for this purpose in the future. However, in those days, overseas troop deployment was simply out of the question (Tanaka, 1997, p. 214).

In 1980, the GoJ developed the legal logic toward overseas military dispatch. Previously, any type of military dispatch outside of the country was called kaigai-hahei (the overseas deployment of armed forces), but a new category of the kaigai-haken (overseas dispatch) was introduced. On the one hand, according to the GoJ, kaigai-habei aims at the use of force and was, therefore, not allowed under the Constitution. On the other hand, kaigai-baken is to send the SDF abroad for purposes other than the use of force. According to the government interpretation in 1980, the new category is not prohibited by the Constitution, but still cannot be 
carried out without a law for this purpose (Asagumo Shimbunsha, 2021, p. 700). The introduction of the new concept of kaigai-haken reconfirmed that new lawmaking in the future might enable the GoJ to contribute the SDF to a UNPKO.

In the 1980s, however, overseas military dispatch was still out of the question, even if it was not for the purpose of the use of force. In 1987, Prime Minister Yasuhiro Nakasone of the LDP attempted to dispatch the MSDF's minesweepers to the Persian Gulf because the US sought assistance from Japan to clear the sea mines laid in the Iran-Iraq War ("Nakasone-shusho ho-bei," 1987). However, this plan soon vanished in smoke, since Chief Cabinet Secretary Masaharu Gotoda emphatically opposed Nakasone's initiative, asserting the "an ant's hole" theory-a small step toward overseas military dispatch would develop into a largescale aggression, just the same as in the prewar era (Kurashige, 2019). This incident attests how firmly the taboo against overseas military dispatch was established in postwar Japan (Fujishige, 2021, pp. 124-125).

\section{The Establishment of the PKO Act}

\subsection{The Gulf War and the First Overseas Dispatch of the SDF}

In 1990, Iraq's invasion of Kuwait marked a turning point for Japan's peacekeeping policy. Around that time, Japan was at the apex of an economic boom, commonly known as the "Bubble Economy," which had emerged from the mid-1980s to the early 1990s. Given its self-confidence in its economic strength, Japan longed to attain status as an international leader. The Gulf Crisis suddenly blew away this naïve wish. The US expected its allies to mobilize support, including military contributions, to liberate the besieged nation from its hostile neighbor, Iraq. However, this expectation was totally unacceptable to the GoJ. Initially, Prime Minister Toshiki Kaifu, another LDP politician, tried to focus on making a huge financial contribution, as well as a small number of civilian personnel contributions. This only resulted in fury from US policymakers, however. Domestically, the LDP's Secretary-General Ichiro Ozawa, whose political power overwhelmed Kaifu's, pushed the prime minister hard for the deployment of the SDF in tandem with the US government. To cope with the dual pressures, the GoJ hinted at the possibility of overseas deployment in 1961, as mentioned earlier, if a new law could be made for this purpose. 
Hence, the GoJ hurriedly attempted to enact a new law in the autumn of 1990 in order to be able to deploy the SDF as part of the US-led multinational coalition forces. But the 1990 bill was soon scrapped. At that time, the ruling LDP had lost its majority in the Upper House and needed to woo support from the moderate opposition parties, namely the Buddhist Komeito Party and the Democratic Socialist Party (DSP), which had split from the JSP. Both of these parties were, however, reluctant to support the controversial bill. Moreover, the lawmaking process was troubled with fierce anti-military resistance, especially from the JSP and the JCP, as well as insufficient time and manpower for thorough preparation.

The aborted bill, however, had the effect of renewing the GoJ's legal logic concerning the contribution of troops to a UNPKO. While tabling the bill at the Diet in October 1990, Director-General of Cabinet Legislation Bureau Atsuo Kudo articulated that the Constitution did not prevent the SDF from joining a UNPKO unless it accompanied the use of force. Even though the bill was soon abandoned, Kudo's (1990) articulation held the hope of another lawmaking. ${ }^{5}$ At the time, it was also confirmed that the SDF contribution must avoid any danger of constituting the use of force.

Early the following year, US-led multilateral forces swiftly swept away the Iraqi forces from Kuwait within two months, but Japan had no presence in this joint military action. Outrage against Tokyo grew in Washington and acute criticisms were widely circulated, accusing Japan of "checkbook diplomacy" and a policy response described as "too little, too late." Moreover, to the GoJ's great shock, the Kuwaiti government did not mention Japan when it ran a full-page advertisement in the Washington Post in March 1991 to thank the countries that had contributed to its liberation. Even if this oversight was the result of a technical error, it was unsurprising that such international criticism and disregard was perceived in Japan as a serious blow. Lastly, the German action had a determinative effect. Just like Japan, Germany contributed no troops during the Gulf War, but it dispatched minesweepers to the Persian Gulf as soon as the war was over. This made the GoJ feel that it had lagged behind. It was at this time that Japan finally realized the importance of a military presence in claiming the status of a full-fledged member of international society.

This realization spurred the GoJ to take prompt action. In April 1991, a month after the end of fighting, they dispatched the MSDF's minesweepers to the Persian Gulf. This decision was made based on an expanded interpretation of the existing SDF Act, which required no additional 
legislation. This marked the first overseas dispatch of the SDF since its foundation in 1954. Within Japan, the anti-military opposition harshly condemned the GoJ for this belated military dispatch, while the majority of public opinion unexpectedly supported it ("Sokai-tei-haken," 1991).

\subsection{The Enactment of the PKO Act}

The "defeat in diplomacy" (Miyagi, 2016, pp. 8-17) nurtured new norms of "International Contribution," which motivated the GoJ to attempt another lawmaking to deploy the SDF to UNPKOs (Fujishige, 2021, pp. 133-172). Learning from the bitter lesson of the previously failed lawmaking, the new bill was prepared in a more cautious manner with much larger manpower. More importantly, Ozawa had already reached a rough agreement with the two moderate oppositions, namely Komeito and the DSP, to secure the majority at the Upper House (The ThreeParties Agreement). Furthermore, the public opinion predicted a more favorable result for this new lawmaking. According to the Asabi survey in June 1991, more than 70 percent of people supported the contribution of the SDF to a UNPKO ("Jiei-tai-kaigai-haken," 1991). Although the antimilitary opposition camp still resisted the new law without compromise, its chance of enactment seemed much greater this time (Fujishige, 2021, p. 149).

In September 1991, the new bill was submitted to the Diet. The GoJ intended to complete this legislation as soon as possible in order to contribute to the SDF from the start of the UNTAC in February 1992 (see Chap. 5). The new lawmaking, however, met fierce resistance from the anti-military opposition. Despite the Three-Party Agreement, the two moderate oppositions were still not entirely cooperative and demanded the insertion of more constraints on the SDF's roles into the new bill. In November 1991, the premiership was passed from Kaifu to another LDP politician, Kiichi Miyazawa. Prime Minister Miyazawa himself was rather reluctant toward the overseas military dispatch, but he pledged to Ozawa, who supported his election as prime minister, that he would enact a new law to deploy the SDF to a UNPKO (Ozawa, 1991). Obliged to fulfill his promise to Ozawa, Miyazawa railroaded the bill through the Lower House in November 1991, with support only from Komeito. Although the bill was passed, the hard measures invited harsh criticism not only from the anti-military opposition but also from the media and public opinion ("Cha-no-ma kara-mo," 1991; "PKO-hoan kyoko-saiketsu," 1991; 
"PKO-kyoryoku-hoan," 1991). The moderate parties also stiffened their attitude.

Consequently, the Miyazawa government was unable to complete the lawmaking in time for the beginning of UNTAC. Despite some setbacks, the GoJ tenaciously persevered with the lawmaking process to pass the bill at the Upper House. Not to repeat the mayhem at the Lower House, the Miyazawa government patiently focused on recovering the commitment from the two moderate parties. Thanks to these persistent efforts, the Miyazawa government finally regained the support of the moderate parties at the price of conceding to their demands to add more restrictions in the new law (see below). Once they had secured the support of the Komeito and the DSP, the success of the lawmaking was assured. Even though the anti-military camp, especially the JSP, continued with its useless resistance, employing the so-called ox-walk tactics, the bill finally passed the Lower House in June 1992. This marked the establishment of the PKO Act. At this point, public opinion still showed a mixed response, fluctuating between pro- and anti-deployment positions ("PKO kyoryoku-ho," 1992), but the GoJ nevertheless undertook immediate preparations to dispatch SDF peacekeepers to Cambodia (see Chap. 5).

\subsection{The Insertion of Strict Constraints into the PKO Act}

To win the support of the two moderate opposition parties, as mentioned earlier, the GoJ had to insert additional stringent constraints into the PKO Act, namely the Five Principles for Deployment (hereafter, the Five Principles), the "freeze" or suspension on the dispatch of Peacekeeping Forces (PKF), and a requirement for advance approval for the PKF's deployment when the "freeze" was removed in the future. First, the Five Principles, which were inserted to meet the demand of the Komeito, had the most extensive impact to constrain the freedom of Japan's peacekeeping policy. The original Five Principles read as follows:

I. Agreements on a ceasefire have been reached among the Parties to Armed Conflict.

II. Consent for the conduct of UN peacekeeping operations as well as Japan's participation in such operations has been obtained from the countries to which the area where those operations are to be conducted belongs as well as the Parties to Armed Conflict. 
III. The operations shall be conducted without partiality to any of the Parties to Armed Conflict.

IV. Should any of the requirements in the above-mentioned principles cease to be satisfied, the International Peace Cooperation Corps dispatched by the Government of Japan may terminate International Peace Cooperation Assignments.

$\mathrm{V}$. The use of weapons shall be limited to the minimum necessity for the protection of the lives of personnel dispatched, in principle (the purpose of "self-preservation").

(GoJ, 1992: MoFA, n.d.)

These Five Principles aimed to eliminate the risk that the SDF might become entangled in the use of force, even if it seemed highly questionable that following these extremely strict regulations would be possible on the ground. In particular, the first three items entailed a very thorny problem because the stipulations rested on the assumption of the classic type of UNPKO. When the PKO Act was passed in June 1992, however, An Agenda for Peace, the radical peacekeeping reform recommendations, was published in the same month and the UNPKO had already set out drastic changes that embraced both "robustness" and "integration" (see Chap. 1). The gap embedded a structural difficulty into the PKO Act to make it very hard for the SDF peacekeepers to cope with the reality in the field.

Another tricky issue was seen in the fifth item of the Five Principles, which authorized the "use of weapons" only for "self-preservation" (Fujishige, 2021, pp. 155-156). ${ }^{6}$ Both the "use of weapons" and "selfpreservation" were unique policy jargon in Japan. First, the concept of "use of weapons" was introduced to allow the SDF peacekeepers to use arms to a minimal degree for self-protection, while avoiding the danger of the use of force. Second, the notion of "self-preservation" is close to the common concept of "personal self-defense" and, therefore, is generally considered as a natural or inherent right to self-protection, which is applicable to all human beings (Koizumi, 2004). In other words, the SDF personnel were naturally entitled to "the use of weapons only for the protection of oneself and others (oneself, SDF members who are at the same scene as oneself)" (MoD, 2019) and this would not constitute the use of force. While the PKO Bill was examined in 1991, the GoJ (1991) defined the "use of weapons for self-preservation" as follows: 
The "use of force" in Article 9 (1) in the Constitution is a concept related to the use of physical power, including the "use of weapons," but the "use of weapons" does not necessarily constitute the use of force, which is prohibited by the clause above. For example, it should be regarded as the natural right to protect oneself and the other SDF members who are at the same scene as oneself, and therefore the minimal "use of weapons" for this purpose is not equivalent to the "use of force," prohibited by Article 9 (1).

Importantly, the GoJ interpreted that the use of physical power in the UNPKOs could constitute the use of force, which is banned by Article 51 of the UN Charter and, accordingly, by Article 9 of the Constitution. Although the UN peacekeepers' use of physical power is described as the "use of force," it is usually distinguished from the "use of force," proscribed by Article 51 of the UN Charter. From the GoJ's point of view, put another way, the "use of weapons" by the SDF peacekeepers escape a risk of constituting the "use of force," banned by the UN Charter and the Constitution and, therefore, it became necessary for the government to fabricate a legal logic to circumvent the possibility of the "use of force."

Under such a backdrop, the GoJ dare to coin the term "selfpreservation." The essence of "self-preservation" is similar to the general concept of "self-defense," which appears in the Three Principles of UNPKOs (UNDPO, n.d.), but the two concepts differ in scope. The Japanese concept of "self-preservation" is narrowly confined to the direct protection of the SDF personnel themselves (as well as their fellow SDF peacekeepers working together), which can be legitimized as a natural right. Meanwhile, the global standard of "self-defense" is more broadly interpreted. The exact nature of the concept of "self-defense" in the UNPKOs is an intricate question because the notion can be interpreted in different ways on different occasions (Cox, 1999). At least, it seems certain that the international notion of "self-defense" can be extended beyond the limited scope of "self-preservation," such as the protection of those who are not SDF personnel but are located at the same scene, or even to somebody who is some distance away, or what Japanese call "coming-toaid" duty (see Chaps. 3, 4, and 8). The GoJ had to introduce these stringent restrictions to be compatible with their peculiar interpretation that the Japanese peacekeepers' use of weapons might constitute the "use of force." In this way, the range of acts for the SDF peacekeepers was constrained by the GoJ's excessively stringent interpretation of the "use of force" (see Chaps. 3 and 4). 
To avoid such a risk, the permitted range of the use of weapons for the SDF peacekeepers was restricted to "self-preservation" rather than the common notion of "self-defense." The gap between the uniquely Japanese notion of "use of weapons for self-preservation" and the international standard of "use of force for self-defense" would generate problems for the SDF peacekeepers on the ground. It was highly problematic because the scope of the concept of "self-preservation" was narrower than that of "self-defense" in the UNPKOs, prohibiting to reach the extent of "use of force." Nevertheless, the original Five Principles of 1992 would be maintained until 2015, when the fifth item was amended (see Chap. 4).

The second restriction was the "freeze" or suspension of the PKF's main duties (see Chaps. 3 and 4). Here lay Japan's peculiar distinction between the "main" and "rear-area" duties for peacekeepers: the former denotes security-related duties, usually carried out by infantry, while the latter means logistical assistance off the front line. In the original PKO Act enacted in 1992, the PKF's main duties were "frozen," restricting the range of the SDF's activities to logistic support only. This restriction was, again, added as a concession to the Komeito's request, since there was a risk that the deployment of an infantry would constitute the use of force. With the suspension of PKF main duties, the SDF peacekeepers would be assigned only logistic support roles, such as engineering, medical care, transportation as well as unarmed military observer roles. Finally, the third restriction established the prerequisite of prior approval from the legislature before dispatching the PKF to fulfill its main duties when the "freeze" was eventually removed. This regulation was inserted to concede to the DSP's request. Even though the "freeze" on the PKF's main duties was removed in 2001, as we will see later, an infantry has, to this day, never been contributed to a UNPKO (see Chaps. 3 and 4). The insertion of these stringent constraints, especially the Five Principles, seriously widened the gap between Japan's domestic legal requirement and the international standard.

\section{Summary of Chap. 2}

In postwar Japan, staunch anti-militarism, and especially a de facto national ban on overseas military dispatch, prohibited any deployment of the SDF abroad. Under such a restriction, military deployment to a UNPKO was simply out of the question. During the Gulf War in 1991, however, Japan faced international criticism concerning its lack of military contribution. 
This humiliating experience made Japan realize the cruciality of military contribution for international peace and security, resulting in the first overseas deployment of the SDF (minesweepers) to the Persian Gulf in April 1991. The momentum for the GoJ continued until the PKO Act was enacted in June 1992. This was an epoch-making lawmaking to institutionalize the SDF's overseas dispatch, but it was formed under a series of strict constraints (e.g., the Five Principles and the "freeze" on the PKF's main duties) to minimize the danger of the SDF's use of force.

\section{Notes}

1. On November 30, 1945, the Ministry of the Army and the Ministry of the Navy were dismantled and converted into the Agency of Demobilization, which was established on December 1, 1945.

2. Although the original text of Article 9 does not have the item numbers, such as (1) and (2), they are inserted here for the reader's convenience.

3. In the early postwar days, there were several conservative parties, such as the Liberal Party, the Democratic Party, and the Democratic Liberal Party. In the political confusion immediately after the war, the conservative camp underwent repeated integration and division until the Liberal Democratic Party (LDP) was established, uniting the conservative-oriented parties, in 1955.

4. The JSP was founded in 1945 but was divided into the Rightist and the Leftist factions in 1950. After the Right and Left factions were reunited in 1955, the JSP became the largest opposition party under the conservativeled single party dominance system (the 1955 system), representing the antimilitary camp. After the end of the Cold War, however, the JSP kept losing seats at the Diet, although they joined the coalition government in 1993 and from 1994 to 1998. In 1996, they changed the party's name to the Socialist Democratic Party (SDP) but their decline continued. In 2009-2010, the SDP joined the Democratic Party of Japan (DPJ)-led coalition government but it kept shrinking. They finally lost their seat at the House of Representatives in the 2017 General Election. The SDP still holds a seat at the House of Councilors. Meanwhile, the JCP was established in 1922 but was illegal and oppressed by the government until the end of World War II. Unlike the JSP, the JCP had never gained the status of the largest opposition party and it remained a marginal party, but it has constantly maintained a certain number of seats at the Diet. At present, the JCP holds 12 out of 465 at the House of Representatives and 13 seats out of 248 at the House of Councilors. 
5. To be precise, Kudo referred to the term "the UN Force" in his statement, but such a force has never been formed and it should, therefore, be understood that he meant a UNPKO.

6. With regard to the Five Principles, another difficult problem appeared regarding the command of Japanese peacekeepers. Once deployed to a UN mission, in principle, peacekeepers are supposed to be placed under UN command. This principle, however, contradicted the third item in the Five Principles, because if this were the case, the GoJ would be unable to decide to withdraw the SDF peacekeepers at its discretion. To create a legal loophole, the GoJ divided the concept of "right of command" into shiki and sashizu: the former means the government's direct right to discipline the SDF peacekeepers, while the latter denotes the UN's overall authority over an entire mission. Again, such peculiar logic did not work outside of Japan, but it helped the GoJ to pass the PKO Act.

\section{ReFerences (In ENGLish)}

Cox, K. E. (1999). Beyond self-defense: United Nations peacekeeping operations $\&$ the use of force. Denver Journal of International Law and Policy, $27(2), 239-274$.

Kowalski, F. (2013). An inoffensive rearmament: The making of the postwar Japanese army (R. D. Eldridge, Ed.). Naval Institute Press.

Kusunoki, A. (2017). The early years of the Ground Self-Defense Forces, 1945-1960. In R. D. Eldridge \& P. Midford (Eds.), The Japanese Ground SelfDefense Force: Search for legitimacy (kindle ed.). Palgrave Macmillan.

MoD. (2019). Framework for activities of the SDF and others after the enforcement of the legislation for peace and security. Defense of Japan (Defense white paper), 248-264. https://www.mod.go.jp/en/publ/w_paper/wp2019/pdf/ DOJ2019_2-5-2.pdf

MoFA. (n.d.). Japan's contribution. https://www.mofa.go.jp/policy/un/pko/ pdfs/contribution.pdf

Mori, T. (2019). Decisions in Japan to use military force or participate in multinational peacekeeping operations. In C. A. Bradley (Ed.), The Oxford handbook of comparative foreign relations law. https://doi.org/10.1093/oxfor $\mathrm{dhb} / 9780190653330.013 .46$

Prime Minister of Japan and His Cabinet. (1947, November 3). The Constitution of Japan. https://japan.kantei.go.jp/constitution_and_government_of_ japan/constitution_e.html

Sado, A. (2017). The self-defense forces and postwar politics in Japan (M. Noda, Trans.). Japan Publishing Industry Foundation for Culture.

UN Charter art. 51. 
UNDPO. (n.d.). Principles of peacekeeping. United Nations Peacekeeping. Retrieved June 22, 2021, from https://peacekeeping.un.org/en/principlesof-peacekeeping

\section{REFERENCES (IN JAPANESE)}

Asagumo Shimbunsha. (2021). Boei-handobuku-2021 [Handbook on defense policy 2021].

Cha-no-ma kara-mo hageshii ikari: PKO-hoan kyoko-saiketsu [The government forcefully passes the PKO Act at the Diet: Ordinary Japanese citizens are furious]. (1991, November 28). Asahi Shimbun (Kanagawa ed.).

Fujishige, H. (2021). Reisen-go ni okeru jiei-tai no yakuwari to sono henyo: Kiban no sokoku to shiyo, soshite "sekkyoku-shugi" eno tenkai (kaitei-ban) [Constructing a more active role: The norm-shift and the rise of activism in Japan's security policy after the Cold War (revised ed.)]. Naigai Publisher.

GoJ. (1991, September 27). Seifu-teishutsu-shiryo "buki no shiyo to buryoku no koshi no kankei ni tsuite" [The GoJ's material on "the relations between the 'use of weapons' and the 'use of force."']

GoJ. (1992, June 19). Kokusai-rengo-heiwa-iji-katsudo-to ni taisuru kyoryoku ni kansuru horitsu [The law regarding cooperation toward the UN peacekeeping and the other operation (original)]. http://www.pko.go.jp/pko_j/data/law/ pdf/law_data07.pdf

Hara, Y. (2000). Sengo-shi no naka no nihon-shakai-to: Sono riso-shugi toha nan-de atta noka [Japan Socialist Party in the postwar history: What was their idealism?]. Chuokoron-shinsha.

Hatakeyama, K. (2018). Nihon no kokusai-heiwa-kyoryoku-seisaku no kigen to tenkai [The origin and evolution of Japan's international peace cooperation policy]. In Y. Uesugi \& H. Fujishige (Eds.), Kokusai-heiwa-kyoryoku-nyumon: Kokusai-shakai eno koken to nihon no kadai [Introduction to international peace cooperation: Japan's contributions to the international community and its policy challenges] (pp. 65-84). Minerva Shobo.

Hayashi, S. (1961, February 22). Dai-38-kai-kokkai, shugi-in, yosan-iin-kai, dai16-go [hatsugen-bango-141] [The 38th Diet, House of Representative, a budget committee, (16), (statement No. 141)]. The 38th Diet. https://kokkai.ndl. go.jp/\#/detail?minId=103805261X01619610222\&spkNum=141\&single

House of Councilors, The National Diet of Japan. (1954, June 2). Sangi-in-honkaigi-ketsugi-hombun, dai-19-kai-kokkai, jiei-tai no kaigai-shutsudo o nasazarukoto ni kansuru ketsugi [House of Councilors plenary session, the 19th Diet, the resolution to refrain from dispatching the SDF abroad]. https://www.sangiin.go.jp/japanese/san60/s60_shiryou/ketsugi/019-57.html 
Ikeda, H. (1961, February 23). Dai-38-kai-kokkai, shugi-in, hon-kaigi, dai-9-go, [hatsugen-bango-6] [The 38th Diet, House of Representative, a plenary session, (9), (statement No. 6)]. The 38th Diet. https://kokkai.ndl.go.jp/\#/det ail? $\operatorname{minId}=103805254$ X00919610223\&spkNum $=6 \&$ single

Jiei-tai-kaigai-haken, $74 \%$ ga yonin: Hi-gunji-gentei ga taisei: Honsha-yoronchosa [Opinion surveys reveal that $74 \%$ of Japanese citizens approve SDF deployment: The majority supports the SDF's non-military operations]. (1991, June 19). Asahi Shimbun, p. 1.

Kato, H. (2020). Jiei-tai-kaigai-haken no kigen [The origin of the overseas dispatch of SDF]. Keiso Shobo.

Kawashima, T. (1997). Shin-kempo-kofu-zengo no kokumin no ishiki-jokyo [Public opinions before and after the adoption of the new Japanese Constitution]. In History Educationalist Conference of Japan (Ed.), Nihonkoku-kempo o kokumin wa do mukaetaka [How did the Japanese citezens accept Japan's Constitution?] (pp. 122-150). Koubunken.

Koizumi, J. (2004, August 10). Shugi-in-giin Sengoku Yoshiro kun teishutsu irakumondai ni kansuru shitsumon ni taisuru toben [The GoJ's response to the questionnaire submitted on the Iraqi issue by the Member of the House of Representatives, Yoshiro Sengoku]. The House of Representatives, Japan. https://www.shugiin.go.jp/internet/itdb_shitsumon.nsf/html/shitsumon/ bl60018.htm

Kongo e jiei-tai o: Matsudaira-taishi, shusho ni shingen: Kokuren-gun-obuzaba toshite haken [Ambassador Matsudaira urges Prime Minister to deploy the SDFs to Congo as UN observers]. (1961, February 22). Yomiuri Shimbun, p. 1.

Kudo, A. (1990, October 29). Dai-119-kai-kokkai, shugi-in, kokusai-rengo-beiwakyoryoku ni kansuru tokubetsu-iin-kai, dai-5-go, [hatsugen-bango-339] [The 119th Diet, House of Representatives, Special Committee on UN Peace Operations, (5), (statement No. 339)]. The 119th Diet. https://kokkai.ndl. go.jp/\#/detail?minId=111904310X00519901029\&spkNum=339\&single

Kurashige, A. (2019, December 17). Tsuito: Nakasone Yasuhiro moto-shusho: Genzitsu-seiji kantetsu-suru hisen no jitsumu-ka: Seiken sasaeta atsui sensokeiken-sha-jimmyaku [Eulogy: Former Prime Minister Yasuhiro Nakasone: A professional politician with realist principles, supported by the wide-ranging networks of the war generations]. Shukan Ekonomisuto [Weekly Economist], 97(49), 15-16.

Miyagi, T (2016). Gendai-nihon-gaiko-shi: Reisen-go no mosaku, shusho-tachi no ketsudan [The history of contemporary Japanese diplomacy: Searching a new way after the Cold War and Prime Ministers' decisions]. Chuko Shinsho.

Nakasone-shusho ho-bei: Nandai-ippai: Perusha-wan: Keizai-masatsu/Nichi-beishuno-kaidan: Kokuren-enzetsu [Prime Minister Nakasone visits the US: Foreign policy challenges facing Prime Minister Nakasone: The Persian Gulf crisis, Japanese-American trade disputes, Japan-US summit and speech at the UN General Assembly]. (1987, September 16). Yomiuri Shimbun, p. 3. 
Omura, S. (1954, December 22). Dai-21-kai-kokkai, shugi-in, yosan-iin-kai, dai2-go [hatsugen-bango-3] [The 21st Diet, House of Representatives, a budget committee, (2), (statement No. 3)]. The 21st Diet. https://kokkai.ndl.go. $\mathrm{jp} / \# /$ detail? $\operatorname{minId}=102105261$ X00219541222\&spkNum=3\&single

Ozawa, I. (1991, December). Dakara ware-ware wa Miyazawa o eranda [And so we chose Miyazawa for new Prime Minister]. Bungeishunju, 69(13), 110-118.

PKO-hoan kyoko-saiketsu de yato-kakuto no hanno [Opposition parties' responses to the forceful passing of the PKO Act at the Diet]. (1991, November 28). Asabi Shimbun, p. 4.

PKO-kyoryoku-hoan, ji-ko no kyoko-saiketsu de sarani settoku-ryoku ushinau [Legitimacy of the PKO Act further declines with its forceful passing at the Diet by the LDP and the Komeito party]. (1991, November 28). Asabi Shimbun, p. 1.

PKO kyoryoku-ho: Hyoka-ni-bun, yureru kokumin-ishiki/Yomiuri-shimbun-shazenkoku-yoron-chosa [Nationwide opinion surveys reveal polarizes public opinions on the new PKO Act]. (1992, June 28). Yomiuri Shimbun, p. 7.

Sado, A. (2015). Jiei-tai-shi: Boei-seisaku no 70-nen [The history of SDF: 70 years of Japan's defense policy]. Chikuma Shinsho.

Sokai-tei-haken, 75\% ga "hitsuyo": "subeki-de-nai" 18\%/Yomiuri-shimbunzenkoku-yoron-chosa [Nationwide surveys reveal that $75 \%$ of Japanese citizens consider that the deployment of minesweepers is necessary, while $18 \%$ oppose this deployment]. (1991, April 26). Yomiuri Shimbun (evening ed.), p. 2.

Tachibana, T. (1983). Nibon-kyosan-to no kenkyu (1) [A study of the Japanese Communist Party, Vol. 1]. Kodansha.

Tanaka, A. (1997). Anzen-hosho: Sengo-50-nen no mosaku [On national security: Trial and error after 50 years since 1945]. Yomiuri Shimbunsha.

Yamagata, T. (2020). Teikoku-riku-kai-gun no sengo-shi: Sono-kaitai, saiben to kyugun-erito [A postwar history of the imperial Japanese army, navy, and air force: Dissolution, reconstitution, and former military elites]. Kyushu University Press.

Yoshida, S. (1946, June 28). Dai-90-kai-teikoku-gikai, shugi-in, hon-kaigi, dai-8gou, [hatsugen-bango-76] [The 90th Imperial Diet, House of Representatives, a plenary session, (8), (statement No. 76)]. The 90th Imperial Diet. https:// teikokugikaii.ndl.go.jp/\#/detail?minId=009013242X00819460628\&spk Num $=76 \&$ single

Yoshida, S. (1950, July 29). Dai-90-kai-kokkai, shugi-in, hon-kaigi, dai-10-go, [hatsugen-bango-18] [The 90th Diet, House of Representatives, a plenary session, (10), (statement No. 18)]. The 90th Diet. https://kokkai.ndl.go.jp/\#/ detail? $\operatorname{minId}=100805254$ X01019500729\&spkNum $=18 \&$ single 
Open Access This chapter is licensed under the terms of the Creative Commons Attribution 4.0 International License (http://creativecommons.org/licenses/ by $/ 4.0 /$ ), which permits use, sharing, adaptation, distribution and reproduction in any medium or format, as long as you give appropriate credit to the original author(s) and the source, provide a link to the Creative Commons licence and indicate if changes were made.

The images or other third party material in this chapter are included in the chapter's Creative Commons licence, unless indicated otherwise in a credit line to the material. If material is not included in the chapter's Creative Commons licence and your intended use is not permitted by statutory regulation or exceeds the permitted use, you will need to obtain permission directly from the copyright holder. 